\title{
Conservation status of primates in Trinidad, West Indies
}

\author{
M. J. Hsu and G. Agoramoorthy
}

This paper presents the results of surveys conducted in 1994 to establish the population size and density, and conservation status of red howler monkeys Alouatta seniculus insulanus and white-fronted capuchin monkeys Cebus albifrons trinitatis in the Trinity Hills, Bush-Bush and Central Range Wildlife Sanctuaries of the Republic of Trinidad and Tobago, West Indies. Populations of the red howler and capuchin monkey have declined by about 25 per cent in BushBush Wildlife Sanctuary over the past 25 years. This decrease was attributed to intensive hunting pressure and habitat destruction. These factors have also caused monkey population declines in the Trinity Hills and Central Range Wildlife Sanctuaries. Recommendations are presented for the local government to enhance the protection of wild monkeys and their habitats in Trinidad.

\section{Introduction}

Trinidad $(4830 \mathrm{sq} \mathrm{km})$ is located approximately $10^{\circ} \mathrm{N} 61^{\circ} \mathrm{W}$ and shares much of the fauna and flora of northern Venezuela, which is approximately $20 \mathrm{~km}$ away at its nearest point (Neville, 1972; Emmons and Feer, 1990). Two species of primates occur in Trinidad: the red howler Alouatta seniculus insulanus and the white-fronted capuchin Cebus albifrons trinitatis (Hill, 1960, 1962; Neville, 1972). Only one previous study (Neville, 1972) has been carried out on the monkeys of Trinidad. Red howlers and white-fronted capuchins were once common throughout Trinidad (Downs et al., 1995), but it has been reported that they have been exterminated in many parts of the island (Neville, 1972). There are no current data available on the conservation status of these monkeys in Trinidad (Wolfheim, 1983). This study was undertaken to investigate the current conservation status of red howlers and capuchins in three major wildlife sanctuaries, the most important in Trinidad for these primates, in the central and southern parts of the country. In this paper, we present data on the population size and density, distribution and conservation of these species in Trinity Hills,
Bush-Bush, and Central Range Wildlife Sanctuaries of Trinidad, West Indies.

\section{Survey sites}

The Trinity Hills Wildlife Sanctuary (6483 ha) was established in 1934 and is the largest wildlife reserve in Trinidad (Bacon and ffrench, 1972). It lies in Mayaro County within the Victoria-Mayaro Forest Reserve, in the south-eastern part of the country. The Trinity Hills, which form part of the southern range of hills, extend over the southern portion of the sanctuary, parallel to the sea coast. The highest point of the southern range is $\mathrm{Mt}$ Derrick $(337 \mathrm{~m})$. The Kapur Ridge $(<80 \mathrm{~m})$ runs through the eastern border of the sanctuary. This ridge also forms a watershed between the Pilote River and its tributaries flowing eastward and the Blackwater, Lucy, Stone, Petite, and Grande Rivers and their tributaries, which flow westward into the Maruga River. The habitat is hardwood forest with the predominant tree species being boismulatre Pentaclethra macroloba, hogplum Spondias mombin, bois-pois Swartzia pinnata, mountain guatecare Escheweilera strinitensis 
and crappo Carapa sp. (Beard, 1946; Downs et al., 1955). This sanctuary has been under mining lease to private and state-run oil companies for at least 30 years. A state-run enterprise, the Petroleum Corporation of Trinidad and Tobago Limited, has had the lease of the sanctuary for the past 8 years. According to Chapter 67:01 of the Conservation of Wild Life Act (Laws of Trinidad and Tobago, 1963), wildlife sanctuaries are protected from encroachment, agricultural expansion, logging, cattle grazing and hunting wild animals. Although game species such as agouti Agouti paca, red brocket deer Mazama americana and collared peccary Tayassu tajacu can be hunted legally, species such as the red howler monkey and whitefronted capuchin monkey are protected by laws (Laws of Trinidad and Tobago, 1963).

The Bush-Bush Wildlife Sanctuary (1550 ha) in Nariva County includes the elevated areas of Bush-Bush Island and Bois Neuf Forest in the seasonally flooded Nariva Swamp (Figure 1). The swamp is fed by the Navet, Bois Neuf and Guatacara Rivers, which drain the eastern slopes of the Central Range. The annual rainfall in the sanctuary averages about $2500 \mathrm{~mm}$ (Downs et al., 1955). The Bush-Bush sanctuary is accessible on foot during the dry season but only by boat during the rainy season because of flooding. The habitat has been classified as hardwood forest (Downs et al., 1955).
The Central Range Wildlife Sanctuary (2153 ha) was established in 1934 and is situated in Caroni, St Andrew and Nariva Counties (Figure 1). Many tributaries of the Talparo and Tumpuna Rivers have their source in this sanctuary. The vegetation is tropical dry evergreen forest, predominant tree species being crappo Carapa guianensis, guatecare Eschweilera subglandulosa, carat palm Sabal glaucescens, acurel Trichilia oblanceolata, mousara Brosimum alicastrum, cedar Cedrela mexicana, balata Mimusops balata, and silk cotton Ceiba pentandra (Beard, 1946; Bacon and Ffrench, 1972). Teak trees Tectona grandis have been planted since the early 1950s (Bacon and Ffrench, 1972) and a teak plantation occupies 40 per cent of the sanctuary.

\section{Survey methods}

Foot surveys along transect lines and forest trails were conducted in Trinity Hills, Central Range and Bush-Bush Wildlife Sanctuaries between March and May 1994. We walked slowly $(1-1.5 \mathrm{~km} / \mathrm{h})$ on the transects and forest trails in the mornings $(07.00-11.00 \mathrm{~h})$ and afternoons (14.00-18.00 h) to record the presence of red howlers and capuchins. The length of transects and forest trails ranged from 5 to $22 \mathrm{~km}$. The survey area was calculated as transect/trail length multiplied by the length of

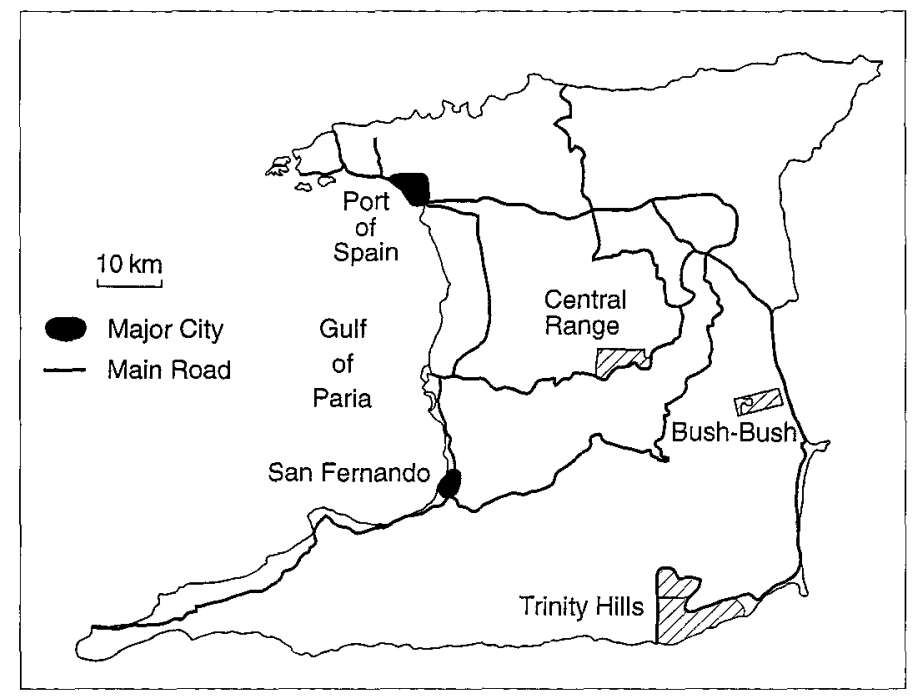

286
Figure 1. Map showing location of Trinity Hills, Bush-Bush and Central Range Wildlife Sanctuaries in Trinidad, West Indies.

(C) $1996 \mathrm{FFI}$, Oryx, 30 (4), 285-291 
visible distance from the trail. A total of 459 ha in Trinity Hills, 84 ha in Central Range and 30 ha in Bush-Bush Sanctuaries was covered during the survey. When howlers or capuchins were heard, we approached them silently until they were in sight. About $20 \mathrm{~min}$ utes were spent recording census data, including: date, time of day, weather (sunny, cloudy, rainy), name of species, number of individuals, location on the field map, height of the tree/canopy ( $m$, estimated visually), sighting angle (measured with a compass), observer to animal distance ( $m$, measured), habitat description (hardwood mangrove, teak plantation), habitat quality (disturbed, undisturbed), sex and age category of individuals (infant, juvenile, adult), and activity upon sighting (feeding, moving, resting). In addition to the census, local villagers were informally interviewed around Trinity Hills $(n=$ 24), Central Range $(n=18)$, and Bush-Bush ( $n$ $=14$ ) Wildlife Sanctuaries, to determine their attitudes towards hunting monkeys. The presence and absence of illegal hunting camps inside wildlife sanctuaries was also noted during the survey. Information on forest destruction, illegal logging and oil pollution in Trinity Hills was collected from informal interviews with local wildlife wardens and during field surveys.

\section{Population status of monkeys}

A total of 92 red howler individuals in 24 groups, 13 in Trinity Hills, six in Bush-Bush and five in Central Range was sighted during this study (Table 1). In addition, six solitary adult males and one subadult female were seen in the three sanctuaries (Table 2). The monkeys were sighted only in the hardwood forests and not in the mangrove vegetation and teak plantation. The group density of red howlers was highest in the Bush-Bush Wildlife Sanctuary ( 0.83 individuals/ha or 20 groups/ sq $\mathrm{km}$ ), and lowest in the Trinity Hills Wildlife Sanctuary ( 0.11 individuals / ha or 2.8 groups / sq $\mathrm{km}$ ).

Thirty-eight capuchin monkeys in seven groups were found in Trinity Hills and Bush-
Bush Wildlife Sanctuaries (Tables 2 and 3). Although only one capuchin group was seen in Bush-Bush Sanctuary, its population density was higher ( 0.27 individuals $/ h a)$ than in Trinity Hills Sanctuary ( 0.07 individuals/ha). The group density of capuchin monkeys was higher in Bush-Bush ( 3.33 groups $/ \mathrm{sq} \mathrm{km}$ ) in comparison with Trinity Hills (1.31 groups /sg km).

The smallest sanctuary, Bush-Bush, had the highest population density of red howlers and capuchin monkeys in comparison with the two larger sanctuaries. The population density of red howlers in Bush-Bush Sanctuary was close to the previously estimated density of red howlers (0.61 individual/ha) at Hato Masaguaral, Venezuela (Neville, 1972). The Wildlife Section of the Forestry Division conducted a survey in 1992 and found about 50 per cent of loss of hardwood forest in BushBush Sanctuary alone between 1988 and 1992 (Seebaransingh, 1993). The destruction was caused primarily by farmers in order to expand their agricultural fields. Cultivating crops, such as rice and watermelon, is active along the borders of the Bush-Bush Sanctuary. Although, during this study, red howlers were seen mostly in social groups (Table 1), some solitary individuals were also seen. This further confirms the previous reports that red howler adult and immature individuals disperse from their natal groups to emigrate into other groups (Rudran, 1979; Agoramoorthy and Rudran, 1993). The average group size of red howlers was $3.5 \pm 1.5$ in Trinity Hills, $3.8 \pm$ 1.2 in Bush-Bush and $4.6 \pm 2.1$ in Central Range, which was about half the average group size of red howlers in Hato Masaguaral $(8.9 \pm 2.5)$, Venezuela (Rudran, 1979; G. Agoramoorthy, unpublished data). In addition, the average group size of red howlers in Bush-Bush Wildlife Sanctuary was noted to have declined from a previously reported size of 7.5 (Neville, 1972) to 3.8 during this study. The reduction in group size of red howlers in Bush-Bush Sanctuary, as well as the sighting of smaller groups in Trinity Hills and Central Range Sanctuaries, may have been due to extensive habitat loss, human predation, and/or natural disasters such as hurricanes, as 
reported earlier for mantled howler monkeys Alouatta palliata on Barro Colorado Island (Collias and Southwick, 1952; Helte et al., 1976). However, howlers are highly adaptable (Hershkovitz, 1949; Wolfheim, 1983) and can survive in isolated patches of hardwood forest in Trinidad if there is no hunting and deforestation.

\section{Illegal logging}

Forest destruction was intense in all three sanctuaries. For example, in Central Range Wildlife Sanctuary alone about 300 trees were illegally logged within a 2-ha plot of forest during the study period. In Trinity Hills, five trees were illegally felled during our survey. Accompanied by a game warden and forester from the Wildlife Section of the Forestry Division of the Ministry of Agriculture, we approached the site to investigate the trees. A few moments later, a hunter who had been hiding in the vegetation within close range shot at us, but we escaped without injury (Agoramoorthy, 1995). The hunter was apparently logging illegally inside the sanctuary and also hunting wild animals. Seven old marihuana Cannabis sativa fields were seen in recently logged areas in Trinity Hills Sanctuary. According to the forestry officials, the marihuana growers usually use booby traps along

Table 1. Composition of red howler groups in Trinidad Wildlife Sanctuaries

\begin{tabular}{|c|c|c|c|c|c|c|c|c|c|c|}
\hline \multirow[b]{3}{*}{ Sanctuary } & \multirow{3}{*}{$\begin{array}{l}\text { Group } \\
\text { no.* }\end{array}$} & \multicolumn{8}{|c|}{ Group composition } & \multirow[b]{3}{*}{ Total } \\
\hline & & \multicolumn{2}{|c|}{ Adult } & \multicolumn{3}{|c|}{ Juvenile } & \multicolumn{3}{|c|}{ Infant } & \\
\hline & & $\bar{M}$ & $\mathrm{~F}$ & $\mathrm{M}$ & $\mathrm{F}$ & $?$ & $\mathbf{M}$ & F & $?$ & \\
\hline \multirow[t]{13}{*}{ Trinity Hills } & 1 & 1 & 1 & - & 1 & - & - & - & - & 3 \\
\hline & 2 & 2 & 2 & 1 & 1 & - & - & - & - & 6 \\
\hline & 3 & 1 & 1 & - & 1 & - & - & - & - & 3 \\
\hline & 4 & 1 & 1 & - & - & - & - & - & - & 2 \\
\hline & 5 & 1 & 1 & - & - & - & - & - & - & 2 \\
\hline & 6 & 1 & 1 & - & - & - & - & - & - & 2 \\
\hline & 7 & 1 & 1 & - & - & - & - & - & - & 2 \\
\hline & 8 & 2 & 1 & - & 1 & - & - & - & - & 4 \\
\hline & 9 & 1 & 2 & 1 & 1 & - & - & - & - & 5 \\
\hline & 10 & 2 & - & - & - & - & - & - & - & 2 \\
\hline & 11 & 1 & 2 & 1 & - & 1 & - & - & - & 5 \\
\hline & 12 & 1 & 2 & 1 & - & 1 & - & - & - & 5 \\
\hline & 13 & 1 & 2 & 1 & - & 1 & - & - & - & 5 \\
\hline Total & & & & & & & & & & 46 \\
\hline \multirow[t]{6}{*}{ Bush-Bush } & 14 & 1 & 1 & - & 1 & - & - & - & - & 3 \\
\hline & 15 & 1 & 1 & - & - & - & - & - & - & 2 \\
\hline & 16 & 1 & 1 & 2 & - & - & - & - & - & 4 \\
\hline & 17 & 1 & 1 & 2 & - & - & - & - & - & 4 \\
\hline & 18 & 1 & 2 & 1 & - & - & - & - & 1 & 5 \\
\hline & 19 & 2 & 1 & 1 & 1 & - & - & - & - & 5 \\
\hline Total & & & & & & & & & & 23 \\
\hline \multirow[t]{5}{*}{ Central Range } & 20 & 2 & 3 & - & 2 & - & - & - & 1 & 8 \\
\hline & 21 & 1 & 1 & 1 & - & 1 & - & - & - & 4 \\
\hline & 22 & 1 & 1 & 1 & 2 & - & - & - & - & 5 \\
\hline & 23 & 1 & 1 & - & 1 & - & - & - & - & 3 \\
\hline & 24 & 1 & 1 & - & - & - & - & - & 1 & 3 \\
\hline Total & & & & & & & & & & 23 \\
\hline
\end{tabular}

* Listed in order observed.

M, male; F, female; ?, sex unknown. 
Table 2. Population densities and group sizes of red howlers and white-fronted capuchins in Trinidad Wildlife Sanctuaries

\begin{tabular}{lllll}
\hline $\begin{array}{l}\text { Sanctuary/ } \\
\text { Species }\end{array}$ & $\begin{array}{l}\text { Area } \\
\text { surveyed (ha) }\end{array}$ & $\begin{array}{l}\text { \% of } \\
\text { sanctuary }\end{array}$ & $\begin{array}{l}\text { Groups/ } \\
\text { sq km }\end{array}$ & $\begin{array}{l}\text { Total no. } \\
\text { individuals* }\end{array}$ \\
\hline $\begin{array}{l}\text { Trinity Hills } \\
\text { Red howlers }\end{array}$ & 459 & 7.1 & 2.8 & 49 \\
$\quad$ Capuchins & 459 & 7.1 & 1.3 & 30 \\
$\begin{array}{l}\text { Bush-Bush } \\
\text { Red howlers }\end{array}$ & 30 & & & \\
$\quad$ Capuchins & 30 & 3.9 & 20 & 25 \\
Central Range & 3.9 & 3.3 & 8 \\
$\quad \begin{array}{ll}\text { Red howlers } \\
\text { Capuchins }\end{array}$ & 84 & 1.9 & 6 & 25 \\
\hline
\end{tabular}

* Includes solitary animals

their fields to keep forestry and other security personnel from entering. However, we did not find any active marihuana fields and traps during this survey. The boundaries of sanctuaries such as Trinity Hills, Bush-Bush and Central Range, also contain the fastest growing villages and towns on the island (Seebaransingh, 1993). As a result, there is an increasing demand for agricultural land near these sanctuaries. Also, the extent of forest clearance, mining for oil exploration, and current agriculture and forestry practices in Trinidad have exposed many areas in and around all three wildlife sanctuaries to accelerated erosion. Forest destruction at BushBush Sanctuary and the adjacent mangrove swamp still continues.

\section{Hunting}

Although monkeys are protected by wildlife conservation law in Trinidad, illegal hunting is continuing in wildlife sanctuaries and 85 per cent $(n=56)$ of the people interviewed around the sanctuaries admitted to either

Table 3. Composition of white-fronted capuchin groups in Trinidad wildlife sanctuaries

\begin{tabular}{|c|c|c|c|c|c|c|c|c|c|c|}
\hline \multirow[b]{3}{*}{ Sanctuary } & \multirow{3}{*}{$\begin{array}{l}\text { Group } \\
\text { no.* }\end{array}$} & \multicolumn{8}{|c|}{ Group composition } & \multirow[b]{3}{*}{ Total } \\
\hline & & \multicolumn{2}{|c|}{ Adult } & \multicolumn{3}{|c|}{ Juvenile } & \multicolumn{3}{|c|}{ Infant } & \\
\hline & & $\mathrm{M}$ & $\mathrm{F}$ & $M$ & $F$ & $?$ & $M$ & $F$ & $?$ & \\
\hline \multirow[t]{6}{*}{ Trinity Hills } & 1 & 2 & 2 & 1 & 1 & 1 & - & - & - & 7 \\
\hline & 2 & 1 & 2 & - & - & 2 & - & - & 1 & 6 \\
\hline & 3 & 1 & 2 & 1 & 1 & 2 & - & - & - & 7 \\
\hline & 4 & 1 & 1 & - & - & - & - & - & - & 2 \\
\hline & 5 & 2 & 2 & - & - & - & - & - & - & 4 \\
\hline & 6 & 1 & 1 & - & - & 1 & - & - & 1 & 4 \\
\hline Total & & & & & & & & & & 30 \\
\hline Bush-Bush & 7 & 2 & 2 & 3 & - & - & 1 & - & - & 8 \\
\hline Total & & & & & & & & & & 8 \\
\hline
\end{tabular}

${ }^{*}$ Listed in order observed.

M, male; F, female; ?, sex unknown.

(C) $1996 \mathrm{FFI}$, Oryx 30 (4), 285-291 
eating or hunting monkeys for meat. The remains of five red howlers (skull, bone and dried skin) were seen at a hunting camp in Trinity Hills Sanctuary during this study. A total of 27 hunting camps was seen in all three wildlife sanctuaries and about 13 of these were located along major forest roads. The Wildlife Section has insufficient staff to patrol the sanctuaries regularly and to enforce legislation concerning hunting and logging. There are 13 wildlife sanctuaries in Trinidad covering an area of about 16,418 ha, which is 3.4 per cent of the total land area (Bacon and Ffrench, 1972); at present there are only 11 game wardens available to patrol all these wildlife sanctuaries.

\section{Oil pollution}

Oil pollution was observed in the Caroni and Stone Rivers of Trinity Hills Sanctuary and apparently there were oil leaks from pipe lines and allocation wells. Oil deposits were also noticed in the Maruga River, especially close to the areas of oil exploration. An estimated 0.08 ha was seen flooded with oil (Seebaransingh, 1993). There were many dead fish and frogs in the rivers. Several tracks of wild mammals, such as red brocket deer, agoutis and monkeys, were seen on the river banks (Agoramoorthy, 1995), and these animals were apparently drinking oil-polluted water. There has been oil pollution in and around Trinity Hills for a long time; during 1987 local residents complained about the oil pollution and reduced yields of fish, crabs and other crustaceans along the coastal fishing ground near the Columbus Channel. The oil pollution from Stone River and its tributaries drained into Maruga River, which flows into the Columbus Channel. Although the Wildlife Section had submitted a report about the oilpollution problems (Seebaransingh, 1993), apparently the government did not take any effective measures either to stop the oil flow or to clean up the oil spill in the rivers.

\section{Recommendations}

1. The destruction of forest lands and expansion of agricultural farms along wildlife sanctuaries must be stopped.

2. Pressure must be brought to bear on the state-run oil company based in Trinity Hills to clean up the oil pollution inside the sanctuary. The oil company should also set up a committee to investigate the extent of oil pollution.

3. A nation-wide ban on hunting of game animals is recommended initially for a period of 5 years to allow the wild animal population to recover. The Forestry Division should fund research projects to investigate the current population status of wild animals in the wildlife sanctuaries and other protected areas of Trinidad.

4. The boundaries of the three wildlife sanctuaries should be marked and warning signs should be posted. Mapping of the current forest cover (using GIS) of the wildlife sanctuaries should be carried out in order to determine the rate of forest loss and eventual management of forest habitats in wildlife sanctuaries.

5. The Wildlife Section of the Forestry Division needs to increase the number of wildlife wardens to patrol the sanctuaries regularly. The security staff of the oil company must co-operate with the wildlife wardens in patrolling the boundaries of Trinity Hills to exclude hunters, loggers and squatters, and to secure safety for biologists and foresters who survey the sanctuary.

6. Public awareness campaigns using posters, television and the press are necessary to explain the illegality of hunting monkeys and other protected species, and the long-term dangers of habitat destruction. A public education campaign targeting village communities around wildlife sanctuaries is essential to promote nature conservation awareness in Trinidad.

7. The Forestry Division may have to explore possibilities of obtaining local revenue through ecotourism centred on bird watching and wildlife viewing. 


\section{Acknowledgements}

This research was supported by a grant from the Conservation and Research Committee of the Chicago Zoological Society. We wish to thank George Rabb for his encouragement, Carol James and Christopher Starr for the invitation to carry out the primate survey, Nadra Nathi-Gyan for providing facilities during the survey, and the families of Moona, Velu and Baggan for their hospitality. The fieldwork was assisted by Glenn Seebaransingh, Philip Cummings, Hipolito Moona, Howard Nelson and Clyde Joshep. We are grateful to the staff of the Wildlife Section and the Forestry Division of the Ministry of Agriculture for their support, friendship and co-operation. We also thank two anonymous referees who provided valuable comments on an earlier version of the manuscript.

\section{References}

Agoramoorthy, G. 1995. Trinidad wildlife sanctuaries in peril. International Primate Protection League News, August, 32-33.

Agoramoorthy, G. and Rudran, R. 1993. Male dispersal among free-ranging red howler monkeys (Alouatta seniculus) in Venezuela. Folia Primatol. 61, 92-96.

Bacon, P.R. and Ffrench, R.P. 1972. The Wildlife Sanctuaries of Trinidad and Tobago. Ministry of Agriculture, Lands and Fisheries, Port of Spain.

Beard, J.S. 1946. The Natural Vegetation of Trinidad. Oxford Forest Mem. No. 20. Clarendon Press, Oxford.

Collias, N. and Southwick, C. 1952. A field study of population dynamics and social organization in howling monkeys. Proc. Am. Phil. Soc. 96, 143-156.

Downs, E.G., Aitken, T.H.G. and Anderson, C.R. 1955. Activities on the Trinidad Regional Virus Laboratory in 1953 and 1954 with special reference to the yellow fever outbreak in Trinidad, B.W.I. Am. J. Trop. Med. Hyg. 4, 837-843.

Emmons, L.H. and Feer, F. $1990 . \quad$ Neotropical Rainforest Mammals. University of Chicago Press,
Chicago.

Helte, A.H., Turner, D.C. and Scott, N.J. 1976. Comparison of census data on Alouatta palliata from Costa Rica and Panama. In Neotropical Primates, Field Studies and Conservation (eds R. W. Thorington and P. G. Helte), pp. 10-19. National Academy of Sciences, Washington DC.

Hershkovitz, P. 1949. Mammals of northern Colombia. Preliminary report no. 4: Monkeys (Primates), with taxonomic revisions of some forms. Proc. US Nat. Museum, 98, 323-427.

Hill, W.C.O. 1960. Primates: Comparative Anatomy and Taxonomy IV. Cebidae, Part A. Edinburgh University Press, Edinburgh.

Hill, W.C.O. 1962. Primates: Comparative Anatomy and Taxonomy IV. Cebidae, Part B. Edinburgh University Press, Edinburgh.

Laws of Trinidad and Tobago, 1963. Conservation of Wild Life Act, Chapter 67:01, Act 16 of 1958, amended by 14 of 1963 . Government of Trinidad and Tobago.

Neville, M.K. 1972. The population structure of red howler (Alouatta seniculus) in Trinidad and Venezuela. Folia Primatol. 17, 56-86.

Rudran, R. 1979. The demography and social mobility of a red howler (Alouatta seniculus) population in Venezuela. In Vertebrate Ecology in the Northern Neotropics (ed. J. Eisenberg), pp. 107-126. Smithsonian Institution Press, Washington DC.

Seebaransingh, G. 1993 Evaluation of Wildlife Habitat and Wildlife Resources. Report to the Wildlife Section, Forestry Division, Port-of-Spain, Trinidad.

Wolfheim, J.H. 1983. Primates of the World: Distribution, Abundance and Conservation. University of Washington Press, Seattle.

Minna J. Hsu, Department of Biology, National Sun Yat-sen University, Kaohsiung 80424, Taiwan.

Govindasamy Agoramoorthy, Conservation and Research Center, National Zoological Park, Smithsonian Institution, Front Royal, VA 22630, USA. 